\title{
Corporate Social Responsibility: A Strategy and Model for Sustainable Growth of Community
}

\author{
Evalyne Jebet Kipchirchir Dr Chris Simon Sitienei Kipkorir \\ School of Business, Kenyatta University, Box 43844-00100 Nairobi City, Kenya
}

\begin{abstract}
The World Commission on Environment and Development in 1987 launched a Sustainable Growth program which was described into three significant concepts called economic, social and environmental sustainability. Sustainable growth works as a model under which communities can utilize resources efficiently, create new businesses to strengthen their economies, establish effective infrastructures, enhance the quality of life, and preserve the environment. Growth in terms of inadequate schools, few medical facilities, electrification and employment has been a challenge to communities. Corporate social responsibility can be used to approach the challenge. The study sought to establish the effect of socio-economic strategy on growth of community surrounding Muhoroni Sugar Company in Kisumu County, Kenya. The study was anchored on corporate social performance theory, with a target population of 13,664 residents, used descriptive research design and stratified random sampling technique to select 121 respondents. Data was analyzed using descriptive and inferential statistics with the aid of the Statistical Package for Social Sciences. The analyzed data was presented in form of pie charts, percentage and frequency distribution tables. The study found out that socio-economic strategy affects growth of community. In conclusion, the company needs to implement socio-economic programs in order to improve schools, health facilities and facilitate creation of employment.
\end{abstract}

Keywords: Corporate Social Responsibility, Strategy, Growth

DOI: $10.7176 / \mathrm{EJBM} / 13-12-03$

Publication date:June $30^{\text {th }} 2021$

\section{Introduction}

Sustainable growth is a process of satisfying human development goals to support the society and the economy and there is need to focus on economic development and social elements as argued by Hohnen and Potts (2007). It can assist the United Nation Foundation to attain the eight Millennium Development Goals established in the year 2000 (Lahiri and Pal, 2009). Sustainable growth is enhanced through training of the community as in the Philippines as argued by Ismail (2009). Globally people acknowledge that the current trend on economic development is unsustainable and therefore public awareness, training and education are the fundamentals for a sustainable society (Ismail, 2009). According to Blewitt, (2015), sustainable growth is regarded as a model under which communities can utilize resources efficiently, create new businesses to strengthen their economies, establish effective infrastructures and enhance the quality of life. Renovation of already existing schools support sustainable growth as argued (Idemudia, 2014). The growth is also enhanced by Non -governmental Organizations buying school textbooks and lab equipment (Kamencu, 2013) and promoted through offering of scholarships by universities and banks (Ndegi, 2014).

Education Partnerships Africa (EPA) is a UK-based NGO which focuses on providing resources to individual primary and secondary schools in Kenya and Uganda. The organization invests in school textbooks, science lab equipment, computers, water, electricity and also support management of these resources and promoting good health and proper sanitation to the school management, the pupils and students (Miller, Welmond, Wolf, 2002). Hong Kong Shanghai banking corporation in China began a 'Read with me program' for one school in 2007 to build on language and literacy of individuals. Education provides the needed training for the community to get employment and therefore elevate the economic status on the individuals (Ismail, 2009). Enriching learning program features volunteer staff does active reading diagnostics to improve the learning levels of students in every grade (Kamencu, 2013). Non-Governmental Organizations focusing on communities have made education as their focal point in community development. They create conducive environment for learning to their host communities (Van Rheede and Blomme, 2013). Today, firms have considered partnering with various colleges and universities to aid them in re-training their employees to gain more knowledge and skills required in workplace. Global firms including Kellog, MAG, Mazac and MUBEA are working together with Gateway Community and Technical College in the United States to develop a center for advanced manufacturing. The technical college customizes its re-training programs to specifically meet the requirement of the workforce. The re-training fee is often covered by the firm itself (Heemskerk, 2012). The author argues that innovation has been a core economic boost which gave birth to multibillion enterprises such as Microsoft, Google, Apple Inc. Starbucks Coffee house and enabled direct and indirect employment opportunities to people. Innovation has activated local economic growth by producing a vibrant society. An excellent contributor to these innovations has been the high-quality education offered in the US. America is using 
education and innovation to create jobs (Hopper, 2016).

The international community of nations has realized that education is vital in human life. This corresponds to the Millennium Development Goals that recognized education as essential for all people to acknowledge their potentials and prioritize completion of primary school curriculum. Education is not an end in itself but also a way of attaining global growth agenda (Henriques and Brilha, 2017). The foundation for worldwide people power (FWPP) in Philippines launched an education revolution program in 2002, because it was strongly believed that it was a feasible solution to poverty (Tokarčíková and Durišová, 2015).

A Vodacom company in Tanzania promote social development through providing road infrastructure, supply of clean water and electricity, education, and health services (Ng'eni; Bukwimba; Kwesigabo and Kaaya, 2015). Likewise, the government of South Africa is encouraging firms to develop socially balanced South Africa through CSR which is greatly valued (Mbirigenda, 2018). In the long run, if a responsible business plan is implemented accordingly, considering sustainable growth, this will as well positively influence the quality of life of the local households.

Co-operative bank of Kenya foundation has also been leading in providing educational scholarships to needy and bright students admitted to various secondary schools in Kenya. Under this program the bank pays school fees for 1400 students in secondary schools and 112 students in various universities in Kenya for four years. The Bank does not require one to take a course in line with its values and functions as normally required (Ndegi, 2014). The United States International University located in Kenya facilitates access to education by the disadvantaged groups through scholarships (Aleixo, Azeiteiro, and Leal, 2016). The author points out that the university sets aside Ksh4 million per year in its annual budget to provide financial aid inform of scholarships, to the bright and needy students. Scholarships are awarded to best two students from the community, diversity scholarship offer fully paid tuition for 3 students; 2 from arid and semi-arid lands and one from informal settlements. The university also sponsors other students to study in other universities abroad.

Azapagic (2004) argues that there should be sustainability in employment. Firms should create and provide jobs to elevate a country's economic growth and builds a stronger community. The author contends that firms empower youth through education in order to create future customers and labor force. Much effort channeled to engineering, math, science and technology, are fundamental for competing in the global market. Sustainable economic growth is not possible if people lack decent quality jobs to boost their economic wellbeing. Sustainable economic growth should provide an environment for job opportunities and proper working conditions for entire population of working age citizens (Hopkins, 2007). There is a possibility of attaining economic growth which in turn impacts positively on social sustainability (Mishra, 2011). European SMEs investors in Kenya have played a vital role in encouraging economic growth through job creation which in the long run would reduce poverty. Furthermore, jobs have enabled the employees to feed their families, educate their children and provide overall social protection (Saito, 2014) These European investors have sparked off use of technology which creates an effective environment to handle work that would otherwise be difficult if there was no technology. Mbirigenda (2018) acknowledges that creation of employment opportunities for sustainable economic growth has been a perennial worldwide ambition to be realized though there has been little remarkable progress made.

Mutea, (2008), argues that offering solutions to various life-threatening sicknesses such as HIV/AIDS, TB, and Cholera etc promote health of the people which in turn would increase firm's profits. In Kenya, there are a number of corporations that have pursued various programs which are directed towards improving the state of health of the community. Nestle Global, a company leading in health and nutrition, launched a kid's program which aims at providing health and nutrition awareness to primary school children. In partnership with the Kenya's ministry of education, Nestle Global targeted fifteen primary schools and enabled the children know the right nutritious foods for good health (Wanjala 2019). In regard to heath society, very little research has been carried out on how firms can promote health through building hospitals which provide affordable and quality health care.

Muhoroni Sugar Company in Kenya, the locale of the current study, has established a primary school called Success primary school with an improved curriculum to offer quality education to the children from the community surrounding the company as argued by Mwangangi and Odhiambo (2013). The author further argues that the company has also established Muhoroni Sugar medical center. The centre provides affordable in-patient and out-patient health services, free medical care for its employees, immunization, family planning services, Voluntary Counseling and HIV Testing services.

\subsection{Objectives}

To determine the effect of social strategy on sustainable growth of

To analyse the effect of economic strategy on sustainable growth of community 


\subsection{Research Hypotheses}

$\mathrm{H}_{01}$. There is no effect of social strategy on sustainable growth of community

$\mathrm{H}_{02}$. There is no effect of economic strategy does on sustainable growth of community

\subsection{Statement of the problem}

Many organizations experience challenges related to sustainable growth which include health, education and weak institutional models. There has been poor infrastructure, few number of hospitals, shortage of drugs and equipment in the hospitals. Inadequacy of proper basic health facilities have caused preventable diseases such as malaria, dysentery and cholera to be predominant hence increased mortality rates as pointed by Moran (2010). Socio-economic challenges confronting community surrounding Muhoroni Sugar Company in education sector include inadequate infrastructure, deficit of permanent primary school classrooms and shortage of learning materials as argued by Mugalavai, (2012). According to Saito (2014) the economic and social welfare could be negatively affected if the environment is not well managed. A survey done by the Standard media group in February 2017 discovered that Kenya has a working age population of 24 million where one out of every six working age Kenyan is unemployed. There are few studies on socio-economic strategy and sustainable growth of community surrounding Muhoroni Sugar Company.

\section{Literature Review}

Critical theory was developed by Castro in 2004 indicating that sustainable growth is merely economic growth based on capitalistic terms. In the current growing body of theoretical discussions about the requirements of achieving sustainable growth, there is criticism arising from the "weak sustainability" model which questions the policy suggesting that the current system of production and consumption could provide sustainable growth. The environmental Marxist point of view suggests the possibility of a sustainable environment grounded on the capitalist economy (Brown, 2002). The main argument is that economic growth depends on the exploitation of natural and social resources. Brown (2002) represents the revolutionary view in sustainable development and the scholar's argument was echoed in Rio and Johannesburg earth summit in 2002.Howes (2005) agrees that it is the duty of the government to facilitate sustainable development of a country by redirecting resources towards sustainable growth. However, there have been uneven gains in advancement in the global economy. Due to the existence of this shortcoming, Strachan, McHarry, Callway and Arye (2005) suggest that a government should have various democratic models to address the interests of the nation. Researchers like Berger, Cunninghan and Drumwrught (2007); Sagebien and Whellams (2010), argue that corporate social responsibility has a no influence on sustainable growth. They claim that businesses require dynamic changes because corporate social responsibility commoditize capital rights and labour as universal norms which often oppose the norms of the community. Moreover, the impression that a responsible corporation can lead to sustainable growth in the long run is being debated because the current market situation prefers firms which come up with solutions through meeting short-term responsibility needs (Sagebien and Whellams, ibid). A capitalistic economy does not advocate for sustainable environment and societal equity to eradicate poverty (Brand, 2009)

Findings from several studies done in Copenhagen and Shanghai showed that smart firms' policies protect and promote health of employees (Vahtera, Kivimäki, Pentti, and Theorell, 2000). Physical exercises such as cycling to work, walking, speedy transit network have been able to reduce injury, lower premature mortality of individuals by $30 \%$ and also reduce cardiovascular disease. Good health is a fundamental part when it comes to sustainable growth of a society. Most of these health policies are made and implemented by the government or the private sector. Moon and Mattenn (2012) carried out a study on dynamics of corporate social responsibility in Asia. The findings showed that education modifies people from rural households to adopt new opportunities hence broaden their sources of income. It happened in China where well educated people in the late 1970s accumulated more capital from the non-agricultural activities. A study was carried out by Henriques and Brilha (2017) concerning corporate social responsibility and education hence sustainable development. The findings indicated that, education eliminates poverty transmission from generation to generation. Evidence from Guatemala City in Mexico indicated that women with high levels of education and cognitive skills led to increase in years in school for their children. Therefore, for every grade completed, the child raises wage by $10 \%$ and if in the reading test the child does well, the child receives $35 \%$ wage increase. These wages would benefit the children as they grow to be adults.

Dumas and Lambert (2005) researched on education and achievement in Senegal and found out that, land or house inheritance does little to eliminate poverty, rather children having parents who completed formal education are most likely to secure off- farm employment and therefore escape poverty. Moreover, in the work of Rose and Dyer (2008) on chronic poverty and education in Ethiopia, it was found out that education is crucial in getting rid of extreme poverty among families. Enhancing levels of education in the rural areas of Ethiopia has made a great impact on poverty between 1995 and 2009. In families where the head has accomplished primary education are likely to escape chronic poverty by $16 \%$. 
Brown (2002) carried out a study in Kenya to find out unemployment rates in Kenya. They discovered that in 2009 , Kenya faced unemployment rate of $42 \%$. Reasons deduced from such high unemployment rate were that dynamics in the labour markets and business cycles have led to an emergent of a high-tech economy where unskilled people have been disadvantaged in securing employment. The findings of Okeyo's (2004) survey in Kenya on firms indicated that those involved in Corporate Social responsibility gain average profit levels. A research carried out by Mulwa (2004) in Kenyan banks concluded that the preferences of the customers influenced their perception on corporate social responsibility. A company with good implemented policies is able to deliver sustainable growth because in corporate social responsibility activities, economic, social, ecological concerns of the community and welfare of businesses are considered (Herrmann 2004). Muhoroni Sugar Company in Kenya provides social and economic services to the community. The company assists the government of Kenya towards achieving sustainable growth. Sifuna (2007 researched on education and poverty elevation in Kenya. The scholar found out that educated micro entrepreneurs are able to effectively run their businesses and gain more profits. In addition, education provides better livelihoods for those working in the informal sectors. The government has ensured that the company's school and health center provide quality services as argued by Mwangangi and Odhiambo (2013). A study done by Osieko (2014) on the effect of Muhoroni Sugar Company in Kenya on the livelihoods of sugarcane growers from the surrounding community indicated that education greatly raises the income of the farmers. A farmer who is well educated is able to interpret and react to emerging information about better utilization of fertilizers, best soil conservation methods, cultivation of cash crops and introduction of new variety of seeds.

\section{Methodology}

The study used descriptive research design with target population of 13,664 and sample size of 121 comprising community residents and Muhoroni Sugar company staff. The sample size was determined with the help of Israel's (1992) 7\% error margin (degree of confidence) with confidence level at 95\%. Stratified random sampling technique was used. Questionnaire was used to collect data which was analyzed using descriptive statistics especially the mean and standard deviation. Inferential statistics such as analysis of variance were used to ascertain significance effect of socio-economic strategy at 5\% level of significance. Multiple regression was used to assess the relationship between the independent and the dependent variables. The analyzed data was presented using frequency distribution tables. Experts were involved and pilot study was carried out to determine the content validity of research instrument. Cronbach's alpha method was used to determine the reliability of research instrument. The standardized Cronbach's reliability coefficient was 0.995 hence acceptable because the threshold of Cronbach's alpha coefficient is of 0.70 . Research Authorization was granted by graduate school, Kenyatta University and National Commission for Science, Technology and Innovation. The respondents voluntarily participated in the study, confidentiality and privacy observed.

\section{Results and Discussion}

Table 1: Social Strategy (Education) and Sustainable Growth of Community Surrounding Muhoroni Sugar Company

\begin{tabular}{|c|c|c|c|c|c|c|c|c|}
\hline \multicolumn{2}{|l|}{ Statements } & SD & $\mathrm{D}$ & UD & A & SA & Mean & Std \\
\hline \multirow{2}{*}{$\begin{array}{l}\text { Muhoroni Sugar Company has done the best } \\
\text { thing in establishing Success Primary School }\end{array}$} & Frequency & 6 & 3 & 4 & 17 & 73 & 4.44 & 1.10 \\
\hline & Percentage & 5.8 & 2.9 & 3.9 & 16.5 & 70.9 & & \\
\hline \multirow{2}{*}{$\begin{array}{l}\text { Success Primary School offers the best } \\
\text { curriculum for my children }\end{array}$} & Frequency & 11 & 5 & 5 & 23 & 59 & 4.11 & 1.34 \\
\hline & Percentage & 10.7 & 4.9 & 4.9 & 22.3 & 57.3 & & \\
\hline \multirow{2}{*}{$\begin{array}{l}\text { My child's performance keeps on improving } \\
\text { every year }\end{array}$} & Frequency & 12 & 7 & 10 & 33 & 41 & 3.82 & 1.34 \\
\hline & Percentage & 11.7 & 6.8 & 9.7 & 32 & 39.8 & & \\
\hline \multirow{2}{*}{$\begin{array}{l}\text { Success Primary School has the best qualified } \\
\text { teaching staff }\end{array}$} & Frequency & 8 & 13 & 5 & 37 & 40 & 3.85 & 1.28 \\
\hline & Percentage & 7.8 & 12.6 & 4.9 & 35.9 & 38.8 & & \\
\hline \multirow{2}{*}{$\begin{array}{l}\text { My children are in a better position to join the } \\
\text { best higher education in future because of } \\
\text { Success Primary School }\end{array}$} & Frequency & 13 & 0 & 5 & 32 & 53 & 4.09 & 1.31 \\
\hline & Percentage & 12.6 & 0 & 4.9 & 31.1 & 51.5 & & \\
\hline \multirow{2}{*}{$\begin{array}{l}\text { I would recommend Success Primary School } \\
\text { for any primary school child }\end{array}$} & Frequency & 0 & 5 & 13 & 36 & 49 & 4.25 & 0.84 \\
\hline & Percentage & 0 & 4.9 & 12.6 & 35 & 47.6 & & \\
\hline \multirow{2}{*}{$\begin{array}{l}\text { Easy accessibility to education determines } \\
\text { sustainable growth of community } \\
\text { Surrounding Muhoroni Sugar Company }\end{array}$} & Frequency & 2 & 5 & 2 & 36 & 58 & 4.39 & 0.90 \\
\hline & Percentage & 1.9 & 4.9 & 1.9 & 35 & 56.3 & & \\
\hline
\end{tabular}
Source: Research data (2018).

The results indicate that $5.8 \%$ of the participants strongly disagreed, $2.9 \%$ disagreed, $3.9 \%$ were undecided, $16.5 \%$ agreed and $70.9 \%$ strongly agreed that Muhoroni Sugar Company has done the best thing in establishing 
success primary school such as Muhoroni Success Primary School (mean of 4.44). Variation in establishing success of primary school was significant (standard deviation of 1.10 ). The findings indicate that $10.7 \%$ of respondents strongly disagreed, $4.9 \%$ disagreed, $4.9 \%$ were undecided, $22.3 \%$ agreed and $57.3 \%$ agreed that Muhoroni Success Primary School offers the best curriculum for the children in the community surrounding Muhoroni Sugar Company especially the employees' children who work at Muhoroni Sugar Company (mean of 4.11). Its variation in curriculum for the children in the community was slightly high (standard deviation of 1.34). According to the results, $11.7 \%$ of residents strongly disagreed, $6.8 \%$ disagreed, $9.7 \%$ were undecided, $32 \%$ agreed and $39.8 \%$ strongly agreed that the pupils' performance in Muhoroni Success Primary School keeps on improving every year (mean of 3.82). Its variation in the pupils' performance was noticeable (standard deviation of 1.34). From the results $7.8 \%$ of participants strongly disagreed, $12.6 \%$ disagreed, $35.9 \%$ were undecided, 38.8\% agreed and 35\% strongly agreed that Muhoroni Success Primary School has the qualified teaching staff (mean of 3.85) with some deviation (standard deviation of 1.28). The findings indicate that $12.6 \%$ of the respondents strongly disagreed, $4.9 \%$ were undecided, $31.1 \%$ agreed and $51.5 \%$ strongly agreed that pupils in Muhoroni Success Primary School are in a better position to join the best higher education in future (mean of 4.09). Chance to join higher education was high (standard deviation of 1.31). The study shows that $4.9 \%$ of the residents disagreed, $12.6 \%$ were undecided, 35\% agreed and $47.6 \%$ strongly agreed that Success Primary School is recommended for any primary school going child (mean of 4.25). Variation in recommending the school for primary school going was low (standard deviation of 0.84 ). Moreover, table 4.3 indicates $1.9 \%$ of the participants strongly disagreed, $4.9 \%$ disagreed, $1.9 \%$ were undecided, $35 \%$ agreed and $56.3 \%$ strongly agreed that easy accessibility to education determines sustainable growth of the community surrounding Muhoroni Sugar Company (mean of 4.39). Variation in sustainable growth of the community was low (standard deviation of 0.90$)$.

Osieko's (2014) study found out that education greatly raises the income of the farmers. This is because; in the $3^{\text {rd }}$ world countries only few people make minimal wages from their farms. Therefore, a well-educated farmer is able to interpret and respond to emerging information on better utilization of fertilizers, best soil conservation methods, cultivation of cash crops and introduction of new seed varieties. However current study focused on the effect of affordable education to children living around Muhoroni Sugar Company. This education would increase literacy and career opportunity for the beneficiaries in the future. Tomno's (2016) research findings indicate that Coca-Cola Company contributes $\$ 88.1$ million annually to a variety of environmental, educational and humanitarian organizations through the Coca-Cola Foundation. It has helped in opening new schools in different regions of the world hence improve the livelihood of the communities. The establishment of Success Primary School has enabled the surrounding community to benefit from affordable and quality education. This in turn has greatly reduced the cost incurred in education in cases where schools are unavailable in the area.

4.1 Qualitative data were collected and summarized as indicated in table 2.

Table 2: Improvements Made in the School

\begin{tabular}{|c|c|c|c|c|}
\hline School improvement & Frequency & Percent & Valid Percent & $\begin{array}{c}\text { Cumulative } \\
\text { Percent }\end{array}$ \\
\hline Equipment and facilities & 35 & 34.0 & 34.0 & 34.0 \\
\hline $\begin{array}{l}\text { Renovation of school in order to } \\
\text { increase enrolment of pupils. }\end{array}$ & 26 & 25.2 & 25.2 & 59.2 \\
\hline $\begin{array}{l}\text { Purchasing of school bus to facilitate } \\
\text { trips for games. }\end{array}$ & 16 & 15.5 & 15.5 & 74.8 \\
\hline $\begin{array}{l}\text { Supporting the children of workers by } \\
\text { paying school fees, }\end{array}$ & 26 & 25.2 & 25.2 & 100.0 \\
\hline Total & 103 & 100.0 & 100.0 & \\
\hline
\end{tabular}

Source: Research data (2018).

From the findings of qualitative data, $34 \%$ of the residents agreed that the school should provide equipment and facilities, 25\% reported that the Muhoroni Sugar Company should renovate the school in order to increase enrolment of pupils. $15.5 \%$ asserted that the school should purchase a school bus to facilitate trips for games among others. $26 \%$ were of the view that Muhoroni Sugar Company should be supporting the workers' children by paying school fees.

Bukwimba, Kwesigabo and Kaaya (2015) support the findings of the current study. They found out that Vodafon Company in Tanzania has helped the community in building schools for the children to access education, hence increasing enrollment of pupils in the school in the region. However, in as much as companies open new schools, they also have an obligation of managing and improving the schools. The findings in the current study showed that it was the responsibility of Muhoroni Sugar Company to not only make improvements in the school through buying more school materials but also provide a school bus and scholarships. 
Table 3. Social Strategy (Health Care) and Sustainable Growth of Community Surrounding Muhoroni Sugar Company.

\begin{tabular}{|c|c|c|c|c|c|c|c|c|}
\hline \multicolumn{2}{|l|}{ Statements } & SD & $\mathrm{D}$ & UD & A & SA & Mean & Std \\
\hline \multirow{2}{*}{$\begin{array}{l}\text { Muhoroni Sugar Medical } \\
\text { Center provides free in-patient } \\
\text { medical services (e.g proper } \\
\text { care for the admitted patients). }\end{array}$} & Frequency & 25 & 33 & 8 & 31 & 6 & 2.61 & 1.30 \\
\hline & Percentage & 24.3 & 32 & 7.8 & 30.1 & 5.8 & & \\
\hline \multirow{2}{*}{$\begin{array}{l}\text { Muhoroni Sugar Medical } \\
\text { Center provides free out- } \\
\text { patient medical services (e.g } \\
\text { quality X-rays, lab tests etc). }\end{array}$} & Frequency & 21 & 31 & 10 & 32 & 9 & 2.78 & 1.32 \\
\hline & Percentage & 20.4 & 30.1 & 9.7 & 31.1 & 8.7 & & \\
\hline \multirow{2}{*}{$\begin{array}{l}\text { Muhoroni Sugar Medical } \\
\text { center offers free maternity } \\
\text { services. }\end{array}$} & Frequency & 18 & 32 & 16 & 29 & 8 & 2.78 & 1.25 \\
\hline & Percentage & 17.5 & 31.1 & 15.5 & 28.2 & 7.8 & & \\
\hline \multirow{2}{*}{$\begin{array}{l}\text { Muhoroni Sugar Medical } \\
\text { Center offers pharmaceutical } \\
\text { drugs at affordable prices. }\end{array}$} & Frequency & 19 & 26 & 12 & 30 & 16 & 2.98 & 1.39 \\
\hline & Percentage & 18.4 & 25.2 & 11.7 & 29.1 & 15.5 & & \\
\hline \multirow{2}{*}{$\begin{array}{l}\text { Muhoroni Sugar Medical } \\
\text { Center has the best qualified } \\
\text { medical staff. }\end{array}$} & Frequency & 12 & 26 & 31 & 29 & 5 & 2.89 & 1.09 \\
\hline & Percentage & 11.7 & 25.2 & 30.1 & 28.2 & 4.9 & & \\
\hline \multirow{2}{*}{$\begin{array}{l}\text { Muhoroni Sugar Medical } \\
\text { Center consistently offer free } \\
\text { ARVs to HIV/AIDs patients. }\end{array}$} & Frequency & 11 & 8 & 22 & 37 & 25 & 3.55 & 1.24 \\
\hline & Percentage & 10.7 & 7.8 & 21.4 & 35.9 & 24.3 & & \\
\hline \multirow{2}{*}{$\begin{array}{l}\text { Health care has an effect on } \\
\text { sustainable growth of the } \\
\text { community surrounding } \\
\text { Muhoroni Sugar Company. }\end{array}$} & Frequency & 10 & 8 & 6 & 41 & 38 & 3.86 & 1.27 \\
\hline & Percentage & 9.7 & 7.8 & 5.8 & 39.8 & 36.9 & & \\
\hline
\end{tabular}

Source: Research data (2018).

The results show that $24.3 \%$ of the participants strongly disagreed, $32 \%$ disagreed, $7.8 \%$ were undecided, and 30.1\% agreed and 5.8\% strongly agreed that Muhoroni Sugar Medical Center provides free in-patient medical services such as proper care for the admitted patients (mean of 2.61). However, free in patient medical services varied slightly (standard deviation of 1.30). From the findings, $20.4 \%$ of residents strongly disagreed, $30.1 \%$ disagreed, $9.7 \%$ were undecided, $31.1 \%$ agreed and $8.7 \%$ strongly agreed that Muhoroni Sugar Medical Center offers satisfactory free out-patient medical services like quality X-rays, lab tests among others (mean of 2.78). There was some variation in provision of free out-patient medical services (standard deviation of 1.32). The findings indicate that $17.5 \%$ of the respondents strongly disagreed, $31.1 \%$ disagreed, $15.5 \%$ were undecided, 28.2\% agreed and 7.8\% strongly agreed that Muhoroni Sugar Medical center generally offers free maternity services (mean of 2.78) with little variation in free maternity services (standard deviation of 1.25).

According to the results, $18.4 \%$ of participants strongly disagreed, $25.2 \%$ disagreed, $11.7 \%$ were undecided, 29.1\% agreed and 15.5\% strongly agreed that Muhoroni Sugar Medical Center offers pharmaceutical drugs at affordable prices (mean of 2.98). Variation in prices was observable (standard deviation of 1.39). Table 4.7 indicates that $11.7 \%$ of the respondents strongly disagreed, $25.2 \%$ disagreed, $30.1 \%$ were undecided, $28.2 \%$ agreed and 4.9\% strongly agreed that Muhoroni Sugar Medical Center has acceptable levels of the best qualified medical staff (mean of 2.89) with little variation (standard deviation of 1.09). In addition, the study shows that $10.7 \%$ of the residents strongly disagreed, $7.8 \%$ disagreed, $21.4 \%$ were undecided, $35.9 \%$ agreed and $24.3 \%$ strongly agreed that Muhoroni Sugar Medical Center consistently offer free ARVs to HIV/AIDs patients (mean of 3.55). There was slight variation in free ARVs to HIV/AIDs patients (standard deviation of 1.24). Moreover, the results indicate that $9.7 \%$ of the participants strongly disagreed, $7.8 \%$ disagreed, $5.8 \%$ were undecided, $39.8 \%$ agreed and $36.9 \%$ strongly agreed that health care has some effect on sustainable growth of the community surrounding Muhoroni Sugar Company (mean of 3.86). There was minimal variation in sustainable growth of community (standard deviation of 1.27). From the findings, majority of participants (77.2\% and mean of 3.86) were of the view that health care has an effect on sustainable growth of the community where Muhoroni Sugar Medical Center offers different health services such as in-patient medical services, quality X-rays, lab tests, free materiality services among others.

The findings concur with Pohl and Tolhurst's (2010) study results which revealed that health plays an important role and good health is an indicator of sustainable growth. It promotes a broader use of health impact assessment in various countries to ensure good health results from all policies. However, the findings of current study revealed that good health is achievable if a company like Muhoroni Sugar Company step in and establish 
fully equipped health facilities for the community. Konar and Cohen (2015) concur with the findings that a firm with a better health performance has a significant positive impact on the firm's market value which is a good predictor of the firm's expected future increase in market size. However, the findings of the current study indicated that if the firm provides quality health facilities, staff become healthy hence improvement in their performance.

\subsection{Qualitative data was collected and summarized as indicated in table 4}

Table 4. Improvement made in the Health Centre

\begin{tabular}{|l|r|r|r|r|}
\hline Health improvement & Frequency & Percent & Valid Percent & $\begin{array}{c}\text { Cumulative } \\
\text { Percent }\end{array}$ \\
\hline Facilities and adequate drugs & 35 & 34.0 & 34.0 & 34.0 \\
\hline $\begin{array}{l}\text { Employment of additional qualified } \\
\text { staff to improve health services }\end{array}$ & 26 & 25.2 & 25.2 & 59.2 \\
\hline $\begin{array}{l}\text { Purchasing of ambulance } \\
\begin{array}{l}\text { Construction more facilities such as x- } \\
\text { rays rooms, expansion of lab }\end{array}\end{array} \quad 16$ & 15.5 & 15.5 & 74.8 \\
\hline Total & 26 & 25.2 & 25.2 & 100.0 \\
\hline
\end{tabular}

Source: Research data (2018).

From the findings, $34 \%$ of the respondents were of the opinion that the Muhoroni health care Centre should improve the facilities and also increase the stock of different drugs, 25.2\% reported the need for employment of qualified staff to improve health services, $15.5 \%$ asserted that the health Centre should purchase ambulance, $25.2 \%$ stated that the health centre should construct more facilities such as X-rays rooms, expansion of lab. The findings indicate that majority of the residents agreed that Muhoroni health care Centre should improve the facility and also increase the stock of different drugs in order to increase efficiency and effectiveness of the health facility.

The current study is supported by Kamencu's (2013) study findings which revealed that through corporate social responsibility, Meru County built health centers hence enabling the community access medication in the health facilities. On the other hand, the study revealed that it was the company's responsibility to ensure the established health centers runs efficiently. In this case, Muhoroni Sugar Company should employ additional quality medical personnel to run the health center, provide ambulance services and adequate drugs and equipment.

Table 5. Economic Strategy and Sustainable Growth of Community Surrounding Muhoroni Sugar Company

\begin{tabular}{|c|c|c|c|c|c|c|c|c|}
\hline Statements & & SD & $\mathrm{D}$ & UD & A & SA & Mean & Std \\
\hline Muhoroni Sugar Company has employed casual & Frequency & 7 & 2 & 18 & 36 & 40 & 3.97 & 1.12 \\
\hline laborers from community surrounding & & & & & & & & \\
\hline Muhoroni Sugar Company & Percentage & 6.8 & 1.9 & 17.5 & 35 & 38.6 & & \\
\hline Muhoroni sugar company has given enough & Frequency & 4 & 8 & 15 & 35 & 41 & 3.98 & 1.10 \\
\hline company & & 20 & & 116 & & 200 & & \\
\hline & Percen & 3.9 & 1.8 & 14.6 & 34 & 39.8 & & \\
\hline Muhoroni Sugar Company has employed & Frequency & 9 & 20 & 31 & 19 & 24 & 3.28 & 1.26 \\
\hline $\begin{array}{l}\text { enough teachers from community surrounding } \\
\text { Muhoroni Sugar Company to work in } \\
\text { Muhoroni Success primary school. }\end{array}$ & Percentage & 8.7 & 19.4 & 30.1 & 18.4 & 23.3 & & \\
\hline Muhoroni Sugar Company has employed & Frequency & 8 & 32 & 32 & 18 & 13 & 2.96 & 1.15 \\
\hline Sugar & & & & & & & & \\
\hline $\begin{array}{l}\text { Company to work in the Muhoroni Sugar } \\
\text { Medical center }\end{array}$ & Percentage & 7.8 & 31.1 & 31.1 & 17.5 & 12.6 & & \\
\hline Muhoroni Sugar Company has employed & Frequency & 12 & 16 & 39 & 20 & 16 & 3.12 & 1.20 \\
\hline $\begin{array}{l}\text { residents of community surrounding Muhoroni } \\
\text { Sugar Company to work at the administrative } \\
\text { departments of the company }\end{array}$ & Percentage & 11.7 & 15.5 & 37.9 & 19.4 & 15.5 & & \\
\hline Economic responsibilities directly influence & Frequency & 12 & 5 & 17 & 34 & 35 & 3.73 & 1.30 \\
\hline $\begin{array}{l}\text { sustainable growth of the community } \\
\text { surrounding Muhoroni Sugar Company }\end{array}$ & Percentage & 11.7 & 4.9 & 16.5 & 33 & 34 & & \\
\hline
\end{tabular}
Source: Research data (2018). 
Findings indicated that $6.8 \%$ of the respondents strongly disagreed, $1.9 \%$ disagreed, $17.5 \%$ were undecided, $35 \%$ agreed and $38.6 \%$ strongly disagreed that Muhoroni Sugar Company has employed casual laborers from the community (mean of 3.97). There was little variation in employing casual laborers from the community (standard deviation of 1.12). The results indicate that $3.9 \%$ of the participants strongly disagreed, $7.8 \%$ disagreed, $14.6 \%$ were undecided, 34\% agreed and 39.8\% strongly agreed that Muhoroni Sugar Company has given enough sugarcane supply tenders to the farmers of community surrounding the sugar Company (mean of 3.98). There was little variation in giving sugarcane supply tenders to the farmers of community surrounding the company (standard deviation of 1.10). According to the findings, $8.7 \%$ of the respondents strongly disagreed, $19.4 \%$ disagreed, $30.1 \%$ were undecided, $18.4 \%$ agreed and $23.3 \%$ strongly agreed that Muhoroni Sugar Company has employed enough teachers from the community surrounding the Sugar Company to work in Muhoroni Success primary school (mean of 3.28). There was some variance in employment of enough teachers from the community (standard deviation of 1.26). Moreover, the findings show that $7.8 \%$ of the participants strongly disagreed, $31.1 \%$ disagreed, $31.1 \%$ were undecided, $17.5 \%$ agreed and $12.6 \%$ strongly agreed that Muhoroni Sugar Company has employed residents from the community surrounding it to work in the Muhoroni Sugar Medical center (mean of 2.96). On average it was disagreeable though variation noticeable (standard deviation of 1.15 ). From the results $11.7 \%$ of the respondents strongly disagreed, $18.5 \%$ disagreed, $37.9 \%$ were undecided, $19.4 \%$ agreed and $15.5 \%$ strongly agreed that Muhoroni Sugar Company has employed residents from the community surrounding Sugar Company Muhoroni town to work at the administrative departments of the company. It had a mean of 3.12 and $\sigma=1.20$. The mean showed there was little multi-collinearity of data. The standard deviation showed some uniformity of data and there was homogeneity of data.

The study indicates that $11.7 \%$ of the residents strongly disagreed, $4.9 \%$ disagreed, $16.5 \%$ were undecided, $33 \%$ agreed and 34\% strongly agreed that economic responsibilities directly influence some sustainable growth of the community surrounding Muhoroni Sugar Company (mean of 3.73). There was little variation in sustainable growth because of economic responsibilities (standard deviation of 1.30). The study findings indicate that majority of residents, $79.6 \%$ (mean of 3.98) were of the view that Muhoroni Sugar Company has given enough sugarcane supply tenders to the farmers from the community surrounding Muhoroni Sugar Company.

The current study findings are supported by Mbirigenda (2018) results which revealed that creation of employment opportunities that ensures sustainable economic growth has for a long time been a worldwide ambition to be realized. However, there has been little remarkable progress made.

The findings concur with the findings of Gillam (2016) which revealed a positive relationship between the corporate social responsibility activities and the financial effects of Brazil Coffee companies where there was 5\% to $8 \%$ increase in profits attributed to corporate social responsibility. It is an indication that corporate social responsibility activities affected the financial performance of the organization. However, the current study reveals that corporate social responsibility initiatives do not only contribute to the company's profit, but also promote the sustainable growth of the community surrounding the firm. Faggio and Konings (2003 studied job reallocation and productivity growth in a manufacturing company and found out that there is need for creation of new jobs, improving working conditions which play a role in economic productivity because many people live on what they earn. However, the current study revealed that apart from job opportunities by the company residents can also benefit by starting enterprises that supply materials to the company. In this case, Muhoroni Sugar Company has been buying sugarcane from the farmers in the area, hence promoting farmer's income.

Table 6. Job Description

\begin{tabular}{|l|r|r|r|r|}
\hline Job description & Frequency & Percent & $\begin{array}{c}\text { Valid } \\
\text { Percent }\end{array}$ & $\begin{array}{c}\text { Cumulative } \\
\text { Percent }\end{array}$ \\
\hline $\begin{array}{l}\text { Casual laborer in the company } \\
\text { Sugar cane supplier }\end{array}$ & 22 & 21.4 & 21.4 & 21.4 \\
\hline $\begin{array}{l}\text { Employed teachers at Muhoroni Success primary } \\
\text { school }\end{array}$ & 13 & 12.6 & 12.6 & 44.7 \\
\hline $\begin{array}{l}\text { Employed staff at Muhoroni sugar medical } \\
\text { center }\end{array}$ & 13 & 12.6 & 12.6 & 57.3 \\
\hline $\begin{array}{l}\text { Employed as the administrative staff in the } \\
\text { company }\end{array}$ & 31 & 30.1 & 30.1 & 69.9 \\
\hline $\begin{array}{l}\text { Total } \\
\text { Sourcer }\end{array}$ & 103 & 100.0 & 100.0 & 100.0 \\
\hline
\end{tabular}

Source: Research data (2018).

From the results $21.4 \%$ of the participants agreed that Muhoroni Sugar Company employ casual workers to carry out firm operations, $23.3 \%$ asserted that it supplies sugarcane to the farmers, $12.6 \%$ stated that the company has employed some teachers from the community to teach at Muhoroni Success primary school, 12.6\% were of the view that the company has employed staff to work at different sections of Muhoroni sugar medical center and $30.1 \%$ reported that it has employed staff to work at the administrative section. From the results majority of respondents agreed that the company has employed staff to work at the administrative section. 
Sagebien and Whellams (2010) found out that Canadian companies have empowered the people in the country through employment hence increasing the community development and livelihood. However, the current study found out that Muhoroni Sugar Company provide employment to the community by establishing schools and health centres. This empowers employment opportunities in other sectors of the economy.

\subsection{Qualitative data was collected and summarized as indicated in table 7.}

Table 7. Improvement of Economic Responsibility

\begin{tabular}{|l|r|r|r|r|}
\hline Economic improvement & Frequency & Percent & $\begin{array}{c}\text { Valid } \\
\text { Percent }\end{array}$ & $\begin{array}{c}\text { Cumulative } \\
\text { Percent }\end{array}$ \\
\hline $\begin{array}{l}\text { Encourage fairness to increase sugarcane planting so } \\
\text { that there is enough cane to crush }\end{array}$ & 22 & 21.4 & 21.4 & 21.4 \\
\hline $\begin{array}{l}\text { Employing staff who are qualified and also casual } \\
\text { workers from the surrounding community }\end{array}$ & 16 & 15.5 & 15.5 & 36.9 \\
\hline $\begin{array}{l}\text { Get involved in service provision such as transport, } \\
\text { harvesting and weeding. }\end{array}$ & 40 & 38.8 & 38.8 & 75.7 \\
\hline Paying farmers in time & 25 & 24.3 & 24.3 & 100.0 \\
\hline Total & 103 & 100.0 & 100.0 & \\
\hline
\end{tabular}

Source: Research data (2018).

Table 7 indicates that $21.4 \%$ of the participants were of the view that fairness be encouraged regarding farmers in order to increase sugarcane planting so that there is enough cane to crush, $15.5 \%$ proposed employment of qualified staff and also casual workers from the surrounding community, 38.8\% reported that Muhoroni Sugar Company should be involved in service provision such as transport, harvesting and weeding and $24.3 \%$ asserted that the company should pay farmers on time. From the study majority of the respondents agreed that Muhoroni Sugar Company should be involved in service provision such as transport, harvesting and weeding.

Osieko (2013) found out that Muhoroni Sugar Company has helped in providing employment to the residents living around the company hence increasing the living standards of the community. The current study further revealed that sustainable employment will be achieved when Muhoroni Sugar Company promote sugarcane farmers through paying their wages on time, employing qualified staff and getting involved in production services such as harvesting and transportation.

Table 8. Analysis of Variance on Social Strategy (Education) Using SPSS Version 24

\begin{tabular}{|l|l|r|r|r|r|r|}
\hline \multicolumn{2}{|c|}{ Model } & Sum of Squares & Df & Mean Square & F & Sig. \\
\hline \multirow{2}{*}{1} & Regression & 43.915 & 35 & 1.255 & 1.757 & $.024^{\mathrm{b}}$ \\
\cline { 2 - 8 } & Residual & 47.838 & 67 & .714 & & \\
\cline { 2 - 8 } & Total & 91.754 & 102 & & & \\
\end{tabular}

a. Dependent Variable: Sustainable Growth of Community Surrounding Muhoroni Sugar Company

b. Predictors: (Constant), Social Strategy Education

Source: Research data (2018).

The table shows that $\mathrm{F}=1.757, \mathrm{p}=0.024$ and the study results indicated that social strategy at 0.05 level of significance where $\mathrm{p}=0.024<0.05$ was significant. The F-calculated (1.757) was more than the F-critical (2.46) which shows that the model was fit in predicting the effect of the social strategy (education) on sustainable growth of community surrounding Muhoroni Sugar Company.

Table 9. Analysis of Variance on Social Strategy (Health Care) Using SPSS Version 24

\begin{tabular}{|l|l|r|r|r|r|r|}
\hline \multicolumn{2}{|c|}{ ANOVA } & \multicolumn{1}{c|}{ F } & Sig. \\
\hline \multirow{2}{*}{1} & & Sum of Squares & Df & Mean Square & 5.521 & $.000^{\mathrm{b}}$ \\
\cline { 2 - 8 } & Regression & 54.017 & 21 & 2.572 & & \\
\cline { 2 - 8 } & Residual & 37.737 & 81 & .466 & & \\
\cline { 2 - 8 } & Total & 91.754 & 102 & & & \\
\end{tabular}

a. Dependent Variable: Sustainable Growth of Community Surrounding Muhoroni Sugar Company.

b. Predictor: (6Constant), Social Strategy Health Care

Source: Research data (2018).

The results indicate that $\mathrm{F}=5.521, \mathrm{p}=0.000$ for the social strategy (health care) at 5 percent level of significance where $p=0.000<0.05$ was significant. The F-calculated $(5.521)$ was more than the F-critical (2.46) which shows that the model was fit in predicting the effect of the social strategy (health care) on sustainable growth of community surrounding Muhoroni Sugar Company. 
Table 10. Analysis of Variance on Economic Strategy Using SPSS Version 24

\begin{tabular}{|c|c|c|c|c|c|c|}
\hline \multicolumn{7}{|c|}{$\mathrm{ANOVA}^{\mathrm{a}}$} \\
\hline \multicolumn{2}{|c|}{ Model } & Sum of Squares & Df & Mean Square & $\mathrm{F}$ & Sig. \\
\hline \multirow[t]{3}{*}{1} & Regression & 53.054 & 16 & 3.316 & 7.369 & $.000^{\mathrm{b}}$ \\
\hline & Residual & 38.700 & 86 & .450 & & \\
\hline & Total & 91.754 & 102 & & & \\
\hline
\end{tabular}

a. Dependent Variable: Sustainable Growth of Community Surrounding Muhoroni Sugar Company

b. Predictor: (Constant), Economic Strategy

Source: Research data (2018).

The table indicates that $\mathrm{F}=7.369, \mathrm{p}=0.000$ revealing that economic strategy at 0.05 level of significance where $p=0.000<0.05$ was significant. The F-calculated (7.369) was more than the F-critical (2.46) which shows that the models were fit in predicting the influence of the economic strategy on sustainable growth of community surrounding Muhoroni Sugar Company.

Table 11. Analysis of Coefficients Using SPSS Version 24

\begin{tabular}{|c|c|c|c|c|c|c|}
\hline \multicolumn{7}{|c|}{ Coefficients $^{\mathrm{a}}$} \\
\hline \multirow{2}{*}{\multicolumn{2}{|c|}{ Model }} & \multicolumn{2}{|c|}{ Unstandardized Coefficients } & Standardized & $\mathrm{T}$ & Sig. \\
\hline & & B & Std. Error & Beta & & \\
\hline \multirow[t]{4}{*}{1} & (Constant) & -1.404 & .532 & & -2.641 & .010 \\
\hline & Social Strategy Education & -.171 & .086 & -.164 & -2.002 & .048 \\
\hline & Social Strategy Health Care & .220 & .090 & .201 & 2.450 & .016 \\
\hline & Economic Strategy & .310 & .124 & .241 & 2.494 & .014 \\
\hline
\end{tabular}

a. Dependent Variable: Sustainable Growth of Muhoroni Community

Source: Research data (2018).

The regression equation is as follows:

$Y=\beta_{0}+\beta_{1} X_{1}+\beta_{2} X_{2}+\beta_{3} X_{3}+\beta_{4} X_{4}+\beta_{5} X_{5}+$ error $(\varepsilon)$

The computed value for $\beta_{1}, \beta_{2} X_{2}+\beta_{3} X_{3}+\beta_{4} X_{4}+\beta_{5} X_{5}$ and the error term as follows

$Y=-1.404-0.171 \mathrm{X}_{1}+0.220 \mathrm{X}_{2}+0.283 \mathrm{X}_{3}+0.310 \mathrm{X}_{4}+0.681 \mathrm{X}_{5}+0.532$

$\mathrm{Y}$ (Sustainable Growth of Community surrounding Muhoroni Sugar Company) $=-1.404-0.171$ (Social Strategy Education $)+0.220$ (Social Strategy Health Care) +0.310 (Economic Strategy) +0.532 (Standard Error).

From the equation it is therefore clear that a unit decrease in social strategy education will vary sustainable growth of community by -0.171 other factors held constant. Also, a unit increase in social strategy health care will vary sustainable growth of community by 0.022 other factors held constant. Moreover, a unit increase in economic strategy will vary sustainable growth of community by 0.310 other factors held constant.

\section{Hypotheses Testing}

The following hypotheses were tested

$H_{01}$. There is no effect of social strategy (education) on sustainable growth of Community Surrounding Muhoroni Sugar Company.

Probability value of $(\mathrm{p}=0.048<0.05)$ was obtained, implying that the hypothesis (there is no effect of social strategy on sustainable growth of community surrounding Muhoroni Sugar Company) was rejected. Osieko's (2014) findings support the current research outcomes which indicate that education empower farmers to earn a higher income which also promote sustainable growth in the community.

$H_{02}$. There is no significant effect on economic strategy on sustainable growth of community surrounding Muhoroni sugar Company.

Table 11 shows a probability value of $\mathrm{p}=0.014<0.05$ which indicate that the hypothesis "there is no effect of economic strategy on sustainable growth of community surrounding Muhoroni Sugar Company" was rejected. Mbirigenda (2018) concurs with the current research findings which indicate that the economic responsibility of companies is to provide employment opportunities for the local community and support innovative projects in the community so as to reduce poverty. CSR comes in and contribute towards bettering the quality of the local community and also for the workforce.

Table 12. Summary of Results On Hypotheses Testing

\begin{tabular}{|l|l|l|}
\hline $\begin{array}{l}\text { Hypotheses } \\
\mathrm{H}_{01} \text {. There is no effect of social strategy (Education) on the sustainable } \\
\text { growth of community surrounding Muhoroni Sugar Company. }\end{array}$ & $\mathrm{P}=0.048<0.05$ & $\begin{array}{l}\text { Hypothesis } \\
\text { rejected }\end{array}$ \\
\hline $\begin{array}{l}\mathrm{H}_{03} \text {. There is no effect of economic strategy on sustainable growth of } \\
\text { community surrounding Muhoroni Sugar Company. }\end{array}$ & $\mathrm{P}=0.014<0.05$ & $\begin{array}{l}\text { Hypothesis } \\
\text { rejected }\end{array}$ \\
\hline
\end{tabular}
Source: Research data (2018). 


\section{Conclusion}

The study found out that socio-economic strategy affects sustainable growth of community. There is need to implement corporate social responsibility programs in order to improve education and health for sustainable growth. The programs improve the status of schools hence increase in enrollment and construction of healthcare facilities. The leads to creation of job opportunities and payment of sugarcane farmers on time which in turn lead to economic development of community.

\section{References}

Aleixo, A.M., Azeiteiro, U.M. and Leal, S., 2016. Toward sustainability through higher education: sustainable development incorporation into Portuguese higher education institutions. In Challenges in Higher Education for Sustainability (pp. 159-187). Springer, Cham.

Antwi, E.K., Otsuki, K., Saito, O., Obeng, F.K., Gyekye, K.A., Boakye-Danquah, J., Boafo, Y.A., Kusakari, Y., Yiran, G.A., Owusu, A.B. and Asubonteng, K.O., 2014. Developing a community-based resilience assessment model with reference to Northern Ghana.

Azapagic, A., 2004. Developing a framework for sustainable development indicators for the mining and minerals industry. Journal of cleaner production, 12(6), pp.639-662.

Berger, I.E., Cunningham, P.H. and Drumwright, M.E., 2007. Mainstreaming corporate social responsibility: Developing markets for virtue. California management review, 49(4), pp.132-157.

Blewitt, J., 2012. Understanding sustainable development. Routledge.

Bondy, K., Moon, J. and Matten, D., 2012. An institution of corporate social responsibility (CSR) in multinational corporations (MNCs): Form and implications. Journal of business ethics, 111(2), pp.281-299.

Brand, F., 2009. Critical natural capital revisited: Ecological resilience and sustainable development. Ecological economics, 68(3), pp.605-612.

Brown, L.A., 2002. Place, migration and development in the Third World: an alternative perspective. Routledge.

Dumas, C. and Lambert, S., 2005. Children's Education in Senegal: How Does Family Background Influence Achievement?. Crest-LMI, Malakoff cedex, France.

Faggio, G. and Konings, J., 2003. Job creation, job destruction and employment growth in transition countries in the 90s. Economic Systems, 27(2), pp.129-154.

Gillam, C.F., 2016. Effects of social and environmental inequalities on the wellbeing of a slum community: the case of Vila dos Pescadores in Southeast Brazil.

Heemskerk, L.P., 2012. How Responsible is Responsible Business? An analysis of the drivers and effects of the responsible business practices of Dutch enterprises operational in Kenyan agribusiness (Master's thesis).

Henriques, M.H. and Brilha, J.B., 2017. UNESCO Global Geoparks: a strategy towards global understanding and sustainability.

Herrmann, K.K., 2004. Corporate social responsibility and sustainable development: The European Union initiative as a case study. Ind. J. Global Legal Stud., 11, p.205.

Hohnen, P. and Potts, J., 2007. Corporate Social Responsibility. An implementation guide for business.

Hopkins, D., 2007. Every school a great school: Realizing the potential of system leadership. McGraw-Hill Education (UK).

Hoppers, W., 2006. Non-Formal Education and Basic Education Reform: A Conceptual Review. International Institute for Educational Planning (IIEP) UNESCO. 7-9 rue Eugene-Delacroix, 75116 Paris, France.

Howes, R. and Robinson, H., 2006. Infrastructure for the built environment: global procurement strategies. Routledge.

Idemudia, U., 2014. Corporate social responsibility and development in Africa: Issues and possibilities. Geography Compass, 8(7), pp.421-435.

Ismail, M., 2009. Corporate social responsibility and its role in community development: An international perspective. Journal of International social research, 2(9).

Kamencu, E. M., 2013 The impact of corporate social responsibility on community social development: A case of Meru municipality. (Unpublished MBA Dissertation, University of Nairobi.

Konar, S. and Cohen, M.A., 2001. Does the market value environmental performance?. Review of economics and statistics, 83(2), pp.281-289.

Lahiri, A. and Pal, J., 2009, December. ICTD in Corporate Social Responsibility: Changing priorities in international development funding. In Second Annual Annual Workshop of the AIS Special Interest Group for ICT in Global Development.

Mbirigenda, S.K., 2018. Community participation in CSR decision making in the contemporary economy and globalization: the case of some selected mobile companies. International Journal Of All Research Writings, 1(2), pp.29-39.

Migwa, D.O. and Wanjala, M.Y., 2019. Factors influencing sustainability of corporate social responsibility projects in the energy sector. A case of Kenya Electricity Generating Company. The Strategic Journal of 
Business \& Change Management, 6(2), pp.572-593.

Miller-Grandvaux, Y., Welmond, M. and Wolf, J., 2002. Evolving partnerships: The role of NGOs in basic education in Africa.

Mishra, S., Lundström, S. and Anand, R., 2011. Service export sophistication and economic growth. World Bank Policy Research Working Paper, (5606).

Mugalavai, V.K., 2012. Challenges and reforms facing Kenyan education system in the 21st century: Integrating the principles of vision 2030 and constitution 2010. Journal of Emerging Trends in Educational Research and Policy Studies, 3(4), pp.471-478.

Mulwa, F.W., 2004. Managing Community-based Development: Unmasking the Mystery of Participatory Development. P. Olivex.

Mutea, F.M., 2008. A survey of the practice of social marketing in christian churches in Kenya (Doctoral dissertation, University of Nairobi).

Mwangangi, A.S. and Odhiambo, R.,2013. The Effect of Community Related CSR on Performance of Manufacturing Firms in Kenya.

Ndegi, R., 2014. The Impact of Corporate Social Responsibility on the Strategic Intent in the Banking Industry in Kenya: A Case Study of Standard Chartered Bank (Doctoral dissertation, United States International University-Africa).

Ng'eni, F.B., Bukwimba, M.L., Kwesigabo, E.M. and Kaaya, I.D., 2015. The Role of Corporate Social Responsibility (CSR) in Community Development in Tanzania. American Journal of Economics, 5(6), pp.609-615.

Osieko, D.O., 2013. Effect of Muhoroni sugar company's practices on livelihood of sugarcane out-growers in Muhoroni District, Kenya (Doctoral dissertation, University of Nairobi,).

Pohl, M. and Tolhurst, N., 2010. Responsible business: How to manage a CSR strategy successfully. John Wiley \& Sons.

Rempel, H., 1981. Rural-urban migration and urban unemployment in Kenya.

Riley, W.J., Moran, J.W., Corso, L.C., Beitsch, L.M., Bialek, R. and Cofsky, A., 2010. Defining quality improvement in public health. Journal of Public Health Management and Practice, 16(1), pp.5-7.

Riley, W.J., Moran, J.W., Corso, L.C., Beitsch, L.M., Bialek, R. and Cofsky, A., 2010. Defining quality improvement in public health. Journal of Public Health Management and Practice, 16(1), pp.5-7.

Rose, P.M. and Dyer, C., 2008. Chronic poverty and education: a review of literature. Chronic Poverty Research Centre Working Paper, (131).

Sagebien, J. and Whellams, M., 2010. CSR and development: Seeing the forest for the trees. Canadian Journal of Development Studies/Revue canadienne d'études du développement, 31(3-4), pp.483-510.

Sifuna, D.N., 2007. The challenge of increasing access and improving quality: An analysis of universal primary education interventions in Kenya and Tanzania since the 1970s. International Review of Education, 53(5), pp.687-699.

Strachan, J.R., McHarry, J., Callway, R. and Ayre, G., 2005. The plain language guide to the World Summit on Sustainable Development. Earthscan.

Tokarčíková, E., Kucharčíková, A. and Durišová, M., 2015. Education of students of the study program informatics in the field of corporate social responsibility. Periodica Polytechnica Social and Management Sciences, 23(2), pp.106-112.

TOMNO, F.J., 2016. Effects of philanthropic corporate social responsibility on strategic positioning of manufacturing firms: a case study of Unilever Kenya (Doctoral dissertation, Kabarak University).

Vahtera, J., Kivimäki, M., Pentti, J. and Theorell, T., 2000. Effect of change in the psychosocial work environment on sickness absence: a seven year follow up of initially healthy employees. Journal of Epidemiology \& Community Health, 54(7), pp.484-493.

Van Rheede, A. and Blomme, R.J., 2013. How to successfully implement sustainability in an organization: A review of the literature. Proceedings of CRRC.

\section{ACKNOWLEDGEMENT}

The researchers acknowledge the contributions of assistant research analyst, library assistants of Kenyatta University, typist and experts who determined validity of the research instrument. We appreciate the respondents, graduate school and National Commission for Science, Technology and Innovation for granting us permission to carry out research. 


\section{AUTHORS' BIOGRAPHY}

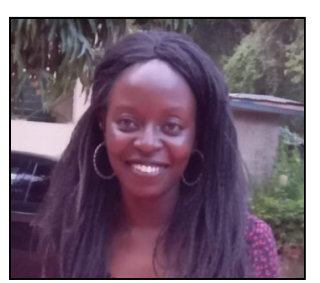

Evalyne Jebet Kipchirchir Ms is Kenyan by nationality born in Kenya. She earned a Master of Business Administration MBA (strategic management) from Kenyatta University, Nairobi, Kenya in 2021. The author completed bachelor's degree in Agriculture and Human Ecology Extension from Egerton University, Nakuru, Kenya in 2015. She is currently the employee of Hand in Hand Eastern Africa as a senior Business Relationship Officer.

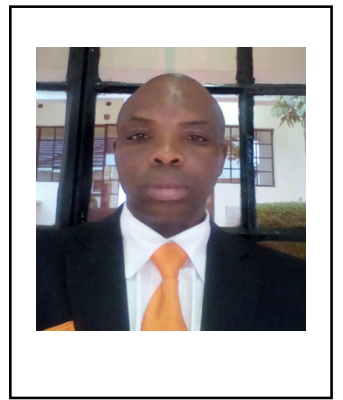

Chris Simon Sitienei Kipkorir, PhD, is Kenyan by nationality born in Kenya. He is a member of Philippines Association of institutions for Research and Association of scholarly peer reviewers. He is currently a full-time FACULTY member, ACADEMIC ADVISER and INTERNAL EXAMINER at Kenyatta University, Nairobi, Kenya. $\mathrm{He}$ is an international PEER REVIEWER on call and was a JUDGE (technical committee member in academic conferences in 2015 Malaysia and 2018 Austria). He has carried out researches on trade policies, knowledge management, operations management, human resource management and strategic management Dr Kipkorir has received a number of academic conference certificates, best paper ward, best presenter and as a judge in a conference. The scholar has published many articles in refereed Journals. He earned a Doctor of Philosophy in Business Administration (PhD BA) in 2013 from the School of Business and Economics, University of San Carlos, Cebu City, Philippines. He completed his Master of Business Administration (human resource management and strategic management) from Kenyatta University, Nairobi, Kenya in 2008. The author earned a bachelor of education degree in arts (Economics and Geography) from Moi University, Eldoret, Kenya in 1994. 